\title{
MEZŐ FERENC ÉS MEZŐ KATALIN KÖNYVE A KREATIVITÁS AZONOSÍTÁSÁRÓL ÉS FEJLESZTÉSI LEHETŐSÉGEIRŐL (RECENZIÓ)
}

\section{A recenzió szerzője:}

Varga-Csikász Csenge (Drs)

Eszterházy Károly Egyetem

Szerző e-mail címe:

varga.csikasz.csenge@gmail.com

\author{
Lektor: \\ Kormos József (PhD) \\ Pázmány Péter Katolikus Egyetem
}

Kelemen Lajos $(\mathrm{PhD})$

Okoskocka Kft.

...és további két anonim lektor

Varga-Csikász Csenge (2020): Mező Ferenc és Mező Katalin könyve a kreativitás azonosításáról és fejlesztési lehetőségeiről (recenzió). OxIPO - interdiszciplináris tudományos folyóirat, 2020/2, 105-107. doi: 10.35405/OXIPO.2020.2.105

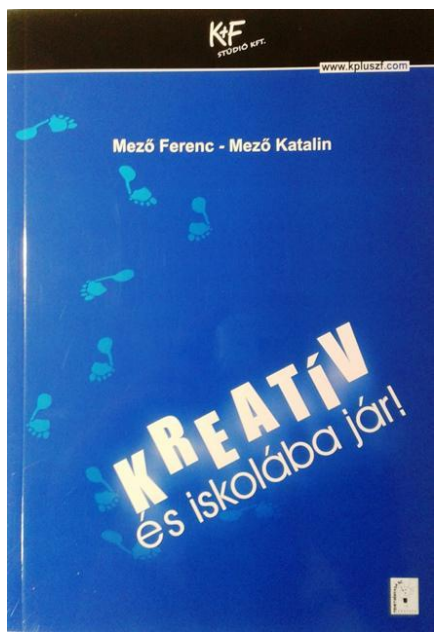

A recenzió alapjául szolgáló mü:

Mező Ferenc és Mező Katalin (2011): Kreativ és iskolába jár. K+F Stúdió, Debrecen. pp.152 ISBN 9789630824354

Kulcsszavak: kreativitás, tehetség, fejlesztés Diszciplína: pedagógia, pszichológia

Bibliography of the subject of this recension: Mező, Ferenc \& Mező, Katalin (2011): Kreativ és iskolába jár. Debrecen (HU): K+F Stúdió Kft.. pp. 152 ISBN 9789630824354

Keywords: creativity, talent, development Disciplines: pedagogy, psychology 
Dr. Mező Ferenc és Dr. Mező Katalin nemcsak a Kreative és iskolába jár! címmel és témával ösztönöznek minket interaktivitásra, hanem a mű szerzői ajánlásával is: az olvasót a borító hátsó részének tanulmányozását követően cselekvésre, a könyv fellapozására szólítják fel. Könyvük címe a téma megjelölése mellett az alkotópár közös kutatási területét, a kreatív tanulás és tehetséggondozás tárgykörét is mutatja. Szülőknek, pedagógusoknak, oktatási intézményeknek és civil szervezeteknek egyaránt ajánlhatjuk művüket.

A fejezetek nem a hétköznapi, megszokott pedagógiai könyvekhez hasonló módon kezdődnek, hiszen az olvasás adta gondolkodási lehetőségek mellett rögtön „bemelegítő gyakorlatokkal” találkozhatunk. Minden nagyobb rész eleje az olvasót aktivitásra, rendszerezésre készteti és - a humoros és egyben tanulságos feladatok révén - nevetésre is ösztönzi. A fejezeteket pedig a témák közötti kapcsolatháló felvázolását célzó gyakorlatok zárják, melyek a korábbi fejetek felidézésére, kreatív, produktív átgondolására késztetik az Olvasót.

A könyv öt nagy fejezetből áll, ezek:

1. A kreativitás története

2. Kreativitás és tehetség

3. A kreativitás azonosítása

4. A kreativitás fejlesztése

5. Eszköztár

Az alábbiakban e fejezetek tartalmi áttekintése következik.
1. A keativitás története címet kapta az első rész, melyben egy kultúrtörténeti áttekintést kapunk a kreativitás útjáról az őskortól kezdve, Platón arisztokratikus nevelésének fogalmán át, a középkori tehetséggondozást, az újkori eugenetikát érintve napjainkig. Megtudhatjuk, hogyan hatottak az intelligenciakutatások a kreativitáskutatásokra, s ez utóbbi területről Guilford divergens gondolkodással kapcsolatos elméletéről és a Szputnyik-sokk fogalmához köthető három kiemelendô eseményről ismerhetünk meg több tényt. A kreativitáskutatás történeti áttekintésére a fejezet végén található zárógyakorlatban maga az Olvasó tehet pontot: szó szerint.

2. Kreativitás és tehetség. Kreativitás és/vagy tehetség? Vajon mi hogyan építenénk fel a könyvnek ezt a részét? - teszik fel a kérdést az írók a második fejezet bemelegitő feladatában, mely fejezet e két fogalom meghatározását, a róluk alkotott ismereteink bővítését célozza. Ebben a részben bővebb információkhoz juthatunk a kreativitás természetét, a kreatív környezetet, produktumot, folyamatot és személyt illetően. A könyv írói a tehetségkoncepciók három fajtaját különböztetik meg: szólnak azokról a tehetségdefiníciókról, amelyek a) a kreativitást nem veszik figyelembe; b) a tehetséget a kreativitással azonosítják; és c) a kreativitást a tehetség szükséges, de nem elégéges öszetevőjének tekintik. A kreativitást a tehetség komponenseként, területeként értékelő tehetségkoncepciók alfejezet címe tükrözi azt a csoportot, melybe a napjainkban is megje- 
lenő koncepciók sokasága beletartozik. Itt a továbbiakban a szerzők által válogatott olyan tehetségmodellekkel találkozhatunk, melyek a kreativitás szerepét emelik ki.

3. A kereativitás azonositásáról szóló rész bemelegítő gyakorlata - ami jelen recenzió szerzőjének személyes kedvence - a hangulat és érzelem észlelés játékkal hívja fel a figyelmet arra, hogyha a személyészlelés legegyszerúbb típusában, az érzelmek jól látható arckifejezéseken keresztül történő felismerésében ennyire különbözőek az észleléseink, akkor vajon mennyiben térhetnek el olyan jellemzők beazonosításában, mint a kreativitás. A fejezet két fő vizsgálati témája a kreatív részképességek és az identifikációs módszerek szemügyre vétele. A szerzők arra a következtetésre jutnak, hogy a kreativitás mérésére még mindig nem sikerült elfogadható mérőeszközt kifejleszteni.

4. A kereativitás fejlesztése című rész tartalmazza az elemi kreativitásfejlesztő technikák és kreativitásprogramok példatárát, illetve ezek fejlesztését. A fejezet arra sarkallja az Olvasót, hogy ő maguk is, mint a fejlesztéssel foglalkozó személyek - legyen az a pedagógus, pszichológus vagy szülő - kreativitásukat alkalmazva használják fel ezeket a módszereket a gyermek kreativitásának mozgósítására. Az „Egy tipikus »kamasz panasz« elemzése" címmel készült táblázat csak egy azon számtalan érdekesség közül, melyek rög- tön rabul ejthetik az olvasó (szülő) tekintetét. Itt kerülnek bemutatásra például: Zsolnai József értékközvetítő és képességfejlesztő programja, Mező Ferenc IPOOmodellje, avagy „A tanulási stratégia” tanulásmódszertani program, a Torranceféle FPS és TCSP programok stb. is.

5. Az Eszköztár - mint ahogy azt a neve is sejteti - olyan megfigyelési szempontsorok, becslőskálák, kérdőívek, tesztek, mérőeszközök gyűjtőhelye, melyek a kreativitás vizsgálata során felhasználhatók. A fejezet összefoglalásában a szerzőpáros ismét felhívja a figyelmet arra, hogy legyünk körültekintőek ezen eszközök alkalmazásakor.

Összegezve ez a könyv olyan elméleti és gyakorlati útmutató, mely felfedi az olvasója előtt, hogy milyen ismeretekkel rendelkezzen az a pedagógus, pszichológus vagy szülő, aki a kreativitás fejlesztésével szeretne foglalkozni. Egyben tájékoztatást kapunk a téma kultúrtörténetéről, arról, hogy milyen kapcsolatban áll a tehetséggel a kreativitás és hogyan ismerhetjük fel a kreatív személyt.

Egyszerre módszergyűjtemény és - a Szerzők szavaival élve - elsôsegély csomag azoknak, akik a kreativitás kutatásának, felfedésének hegyét-völgyét kívánják bejárni: ezen a túrán elindulókat kalauzolja Mező Ferenc és Mező Katalin „Kreatív és iskolába jár!" című munkája. 